SIT Graduate Institute/SIT Study Abroad SIT Digital Collections

Capstone Collection

SIT Graduate Institute

Spring 5-19-2016

\title{
Queering Colombia's Peace Process: A case study of LGBTI inclusion
}

Nicole Maier

SIT Graduate Institute

Follow this and additional works at: https://digitalcollections.sit.edu/capstones

Part of the Gender and Sexuality Commons, and the Latin American Studies Commons

\section{Recommended Citation}

Maier, Nicole, "Queering Colombia's Peace Process: A case study of LGBTI inclusion" (2016). Capstone Collection. 2886.

https://digitalcollections.sit.edu/capstones/2886

This Thesis (Open Access) is brought to you for free and open access by the SIT Graduate Institute at SIT Digital Collections. It has been accepted for inclusion in Capstone Collection by an authorized administrator of SIT Digital Collections. For more information, please contact

digitalcollections@sit.edu. 


\title{
QUEERING COLOMBIA'S PEACE PROCESS: A CASE STUDY OF LGBTI INCLUSION
}

\author{
Nicole Maier \\ PIM 73 \\ A Capstone Paper submitted in partial fulfillment of the requirements for a Master of \\ Arts in Peacebuilding and Conflict Transformation at SIT Graduate Institute in \\ Brattleboro, Vermont, USA. \\ May 16, 2016 \\ Advisor: Dr. Teresa Healy
}




\section{Consent to Use of Capstone}

I hereby grant permission for World Learning to publish my capstone on its websites and in any of its digital/electronic collections, and to reproduce and transmit my CAPSTONE ELECTRONICALLY. I understand that World Learning's websites and digital collections are publicly available via the Internet. I agree that World Learning is NOT responsible for any unauthorized use of my capstone by any third party who might access it on the Internet or otherwise.

Student name: Nicole Andreya Maier _ Date: May 16, 2016__ 


\section{DEDICATION \& ACKNOWLEDGEMENTS}

To my Dad who gave me the gift of curiosity...

To my Mom who gave me the gift of confidence...

To my Husband who gave me the gift of partnership...

Thank you for giving me the gift of unconditional love and support.

"Injustice anywhere is a threat to justice everywhere." - Martin Luther King Jr. 


\section{TABLE OF CONTENTS}

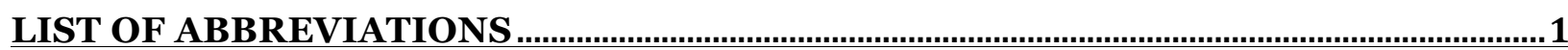

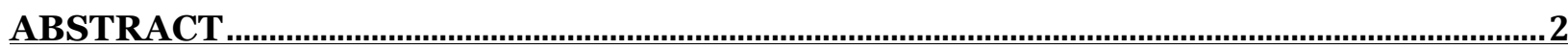

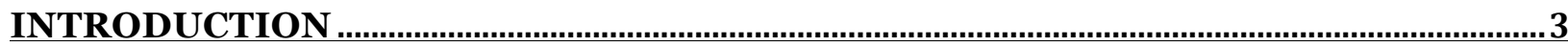

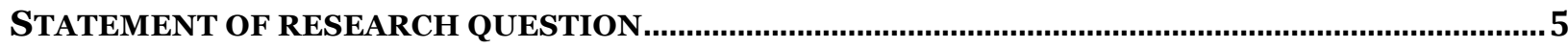

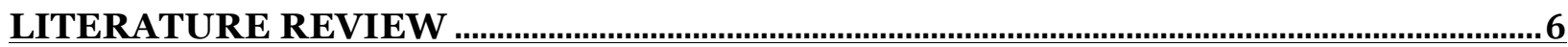

TRANSITIONAL JUSTICE \& INCLUSIVE TRUTH-SEEKING INITIATIVES .......................................... 7

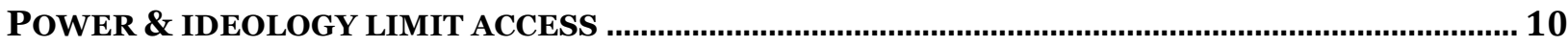

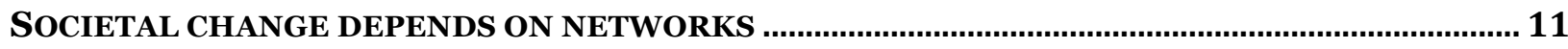

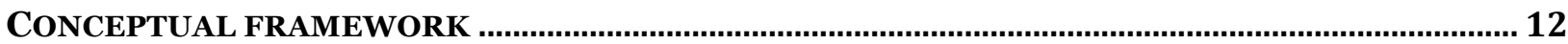

PRACTITIONER INQUIRY DESIGN

PRESENTATION AND ANALYSIS OF DATA

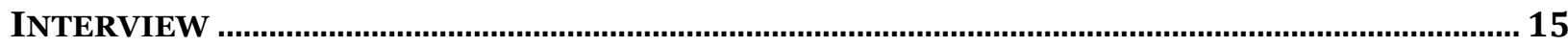

PRESENTATIONS TO THE NEGOTIATION TABLE BY LGBTI ORGANIZATIONS ............................ 21

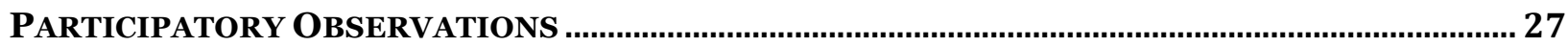

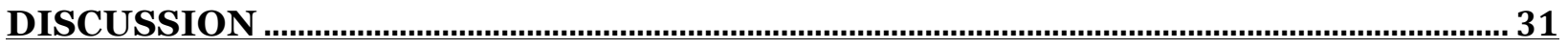

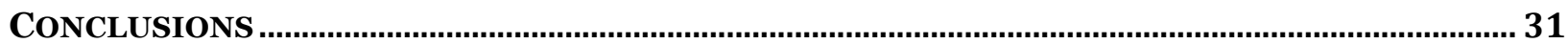

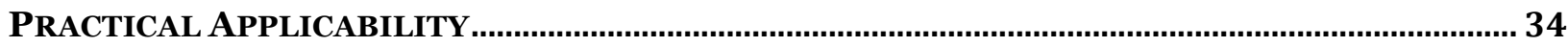

RECOMMENDATIONS FOR FURTHER RESEARCH....................................................................... 35

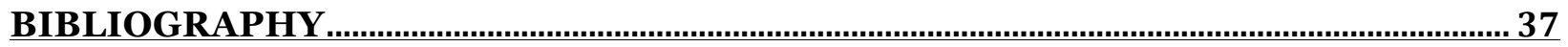

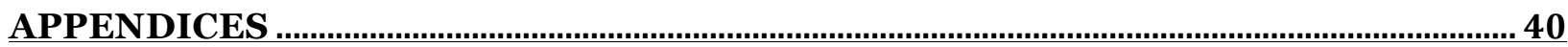

APPENDiX A: INTERVIEW QUESTIONS FOR ADVOCATES FROM COLOMBIA DIVERSA IN ENGLISH AND

SPANISH 


\section{LIST OF ABBREVIATIONS}

ELN

FARC-EP (FARC)

ICTJ

LGBTI

UN
National Liberation Army

Revolutionary Armed Forced of Colombia - People's Army

International Center for Transitional Justice

lesbian, gay, bisexual, transgender, intersex

Untied Nations 


\begin{abstract}
Colombia has suffered under its current armed conflict for more than half a century. There is finally a glimmer of hope with the progression of peace talks between the Colombian government and the country's largest guerrilla group, the Revolutionary Armed Forces of Colombia (FARC). These talks began in 2012 and have experienced a number of successes and failures thus far. However, they have been regularly praised and revered as a model for the world, particularly with regard to their efforts surrounding victims of the armed conflict. This capstone paper focuses on one particular group of victims, lesbian, gay, bisexual, transgender, and intersex (LGBTI) individuals. The experience of LGBTI people in armed conflicts has been historically excluded from peace processes. I explore how Colombia's peace process has approached the LGBTI experience through interviews with LGBTI activists, analysis of the actions taken by the negotiators, and my own observations throughout my internship in Bogotá, Colombia. This case study highlights the complexity of social discrimination and violence against LGBTI individuals in Colombia and that occurs within the context of the armed conflict. The efforts conducted by LGBTI organizations reveal the critical role of truth and memory initiatives and capacity building. While much work has been done to ensure the inclusion of an LGBTI agenda in the peace process, Colombia is left with many unanswered questions about what a post-conflict society will look like for LGBTI victims of the armed conflict.
\end{abstract}




\section{Introduction}

While attending a conference in Bogotá, Colombia in March of 2015, I heard a story of a young woman who had been an advocate for women's rights in her community. This woman was also a lesbian but had only come out to her family and close friends. Her friend who was sharing her story at the conference suggested that the family's disapproval of the woman as a lesbian increased her vulnerability for attack by armed actors in Colombia's half-century long armed conflict. The woman's name was listed on an all too common pamphlet that had been distributed around the town threatening to cleanse the town of people like her. The friend shared that one day there was a raid on a popular gathering place for members of the LGBTI community conducted by the armed group who had distributed the pamphlet. This young woman was there and disappeared that day, her body has yet to be found. This story was unfortunately one of many similar stories describing the experience of Colombia's internal armed conflict from the perspective of lesbian, gay, bisexual, transgender, and intersex (LGBTI) ${ }^{1}$ victims.

Colombia has suffered under a civil war that has lasted over 50 years. Colombia's experience with war is characteristic of what John Paul Lederach refers to as a contemporary conflict. According to Lederach (1997), a contemporary conflict is marked by being locked in a cycle of confrontation and negotiation. Colombia has had a handful of start-and-stop peace talks over the last 30 plus years with two of its most prominent guerrilla groups (Alsema, 2012), the Revolutionary Armed Forces of Colombia People's Army (known by its Spanish acronym, FARC-EP) and the National Liberation

\footnotetext{
${ }^{1}$ These four identities have been chosen because they are the most commonly referred to in the Colombian context. While the queer identity is very prominent in the United States, hence the acronym LGBTQ, this term has not experienced the same reclaiming by the community in Colombia.
} 
Army (ELN), both formed in 1964 (BBC, 2013). Colombia's cycle of confrontation and negotiation has resulted in at least 220,000 dead and over 5.7 million displaced over the past five decades (Renwick \& Hanson, 2014). This staggering number of victims is made even more overwhelming when one considers the number of family members affected by the loss of their loved ones and the number of communities terrorized by guerrillas and paramilitaries, along with many others. As of May 1, 2016, the Victim's Unit of the government of Colombia has registered more than 8 million victims of the armed conflict nation-wide (Red Nacional de Informacion, 2016). These are the individuals most affected by the locked cycle described by Lederach. This capstone paper focuses on a particularly marginalized group of victims: the LGBTI population.

In my role as an intern for the International Center for Transitional Justice (ICTJ) in Bogotá, I attended a training with my supervisor in rural Colombia. The purpose of this training was to empower women victims of the armed conflict by teaching them about their human rights and connecting them to transitional justice mechanisms to ensure those rights. My supervisor was an educated lawyer from the capitol city entering into a space with mostly uneducated and illiterate women from rural towns. There was a clear disconnect between my supervisor's theoretical relationship with the content and the participants' lived experience with the violence. Unfortunately, many of the women appeared confused by the academic terminology presented by my supervisor. Ultimately, the training did not seem to meet the needs of the participants, which led me to question what is the role of human rights leaders like my supervisor in equipping those groups most impacted by the conflict to participate in the peace process. I wondered about other leaders and their ability to effectively communicate with and train other groups of victims. 
I was later invited to attend the conference for LGBTI victims of the armed conflict that I described at the start of this paper. The conference was organized by three prominent LGBTI organizations in Colombia - Colombia Diversa, Caribe Afirmativo, and Santamaría Fundación - along with ICTJ. This conference introduced me for the first time to the voices of LGBTI victims of the armed conflict. My observations of the victims' participation showed me that they felt much more comfortable engaging with the topics than did the participants at the training with my supervisor. The contrast between these two observations of victim participation with civil society leaders made me consider what is the relationship there and how are civil society leaders using their positions to further the inclusion of victims in the peace process. I became particularly interested in the LGBTI perspective as a result of this conference.

I later read an interview with United States Institute of Peace Senior Adviser Virginia Bouvier, where she was praising a recent breakthrough in Colombia's peace talks with regard to transitional justice and victims as a model for the world (Strasser, 2015). Bouvier was cited as referring to Colombia's peace process as an “...example of how process affects outcome, and how inclusion of marginalized sectors can improve agreements" (Strasser, 2015). The news of these high praises for Colombia's peace process juxtaposed with my observations of the training and the conference left me wondering. How was Colombia able to warrant such international support for its ability to integrate victims in its peace process?

\section{Statement of research question}

I reflected on the question stated above through the lens of my internship at ICTJ. During my internship, I was tasked with researching civil society initiatives for 
justice and reparations for victims, which inspired me to explore the work of LGBTI civil society organizations in Colombia. As it turns out, there is much work being done among the LGBTI community with regard to education and advocacy in general and specifically related to the armed conflict. I found this to be extremely encouraging and at the same time rare. My preliminary research into other armed conflicts and their focus on the inclusion of victims, specifically those who identify as LGBTI, bore disappointing results. Very few documents produced post-armed conflict even mention sexual and gender minorities let alone describe efforts made to include them in a process to resolve an armed conflict. This lack of information worldwide and the active work being done in the Colombian context validated my curiosity and led me to the research question guiding this capstone paper: To what extent are civil society leaders in Colombia creating a peace process that is inclusive of LGBTI victims of the armed conflict?

\section{Literature Review}

My initial search of the literature revealed that, despite all the efforts I observed in country, very little had been written on the Colombian LGBTI experience in peacebuilding. This led me to reflect on more general issues that would be most relevant to my research question. After reviewing the literature with this perspective, the following themes emerged: inclusive truth-seeking initiatives are essential in peacebuilding; power and dominant ideologies limit access of LGBTI people to peacebuilding processes; and societal change depends upon networks built by individual leaders and organizations. 


\section{Transitional justice \& inclusive truth-seeking initiatives}

My internship, the training with my supervisor, the conference I attended, and the justice for victims agreement that came out of the peace talks all dealt with the topic of transitional justice. Transitional justice has become a leading approach to peacebuilding in recent years; particularly focused on the difficult transition period society's face when moving from a period of violence to one post-violence. According to the United Nations (2010), "transitional justice is the full range of processes and mechanisms associated with a society's attempt to come to terms with a legacy of largescale past abuses, in order to ensure accountability, serve justice and achieve reconciliation" (p. 2). ICTJ (n.d.-b) adds to the United Nations' definition by delineating four primary but not exclusive elements of a comprehensive transitional justice plan: criminal prosecutions, reparations, institutional reform, and truth commissions. Truth commissions have a strong history in Latin America and are considered one form of a more all encompassing effort known as truth-seeking initiatives, which play a critical role in "documenting and acknowledging human rights violations" (ICTJ, n.d.-a, para. 1). Truth-seeking initiatives are considered part of the non-judicial measures that make up the field of transitional justice (United Nations, 2010). Given my experience as the Truth and Memory Intern for ICTJ and the fact that I'm not a trained lawyer, my focus is on the non-judicial measure of truth-seeking initiatives.

Katherine Fobear, in her article Queering Truth Commissions (2014), argues that there is a long history of anti-queer violence that has not received sufficient attention in truth-seeking initiatives and views truth commissions as uniquely situated to address these inadequacies. She discusses the importance of incorporating sexual and gender minorities in the development and planning of such truth-seeking initiatives. Informed 
by her work in Peru, Kimberly Theidon emphasizes that one goal of a truth commission is creating new narratives that are more inclusive of historically marginalized groups (as cited in Fobear, 2014). Together, Fobear and Theidon present an opportunity within truth-seeking initiatives for the LGBTI population to receive acknowledgment of the violence they've experienced, much like the role played by ICTJ, to become active participants rather than just subjects of investigation, and to contribute to a more accurate record of the past.

While LGBTI victims have historically been left out of most truth-seeking initiatives, the arguments in favor of including them persist. Martina Fischer (2011) adds to this discussion of inclusion by emphasizing the importance of civil society actors' involvement at every step of the war-to-peace transition. While Fischer does not directly refer to truth-seeking initiatives, recognizing that they are part of the war-topeace transition, her arguments for inclusion are relevant here. Fischer reasons that peace processes will be more effective if they include broader societal perspectives, reiterating Theidon's point of creating more inclusive narratives. Much like Fobear's recommendation with regard to sexual and gender minorities, Fischer claims that inclusion in the process from beginning to end is the only way to incorporate the perspectives of women, citing evidence of this from the United Nations. Given that both women and LGBTI individuals are historically marginalized groups, these arguments shed light on the need to include LGBTI civil society actors - not just individual sexual and gender minorities - in peacebuilding. The collective representation of marginalized groups in the form of civil society actors allows for coordinated participation in the warto-peace transition described by Fischer. 
In addition to the discussion of the opportunities of an inclusive truth-seeking process for the LGBTI population, the literature offers a responsibility to fulfill the right to truth. This right has become commonly agreed upon as a human right in many international agreements ${ }^{2}$. An individual's and societies' right to truth also provides the opportunity for proper mourning and healing (ICTJ, n.d.-b). John Paul Lederach proposes another significant role played by truth. He describes that the meeting place between truth, mercy, justice, and peace is known as reconciliation (Lederach, 1997). Lederach argues "truth is the longing for acknowledgment of wrong and the validation of painful loss and experiences" (p. 29). These ideas of accurate documentation, acknowledgment, feelings of loss and mourning have been echoed by each author discussed here. This role truth plays in repairing societies is particularly crucial to reconciliation for the LGBTI population, a marginalized group who is not only victimized within the context of the armed conflict but who have been wronged throughout history. The exclusion of the voices and experiences of LGBTI people and the strong support within the literature for the critical role of truth-seeking initiatives in peacebuilding demand research such as this to continue to claim space for marginalized groups.

One challenge to inclusion found in the literature is highlighted by an explanation for the historical exclusion of sexual and gender minority groups. Fobear (2014) offers a reality of sexual identity where it is never experienced in isolation, but rather is intertwined with other social positioning, such as race, gender, class, and geopolitical spatialization. This intersectionality of identities provides insight into how sexual

\footnotetext{
${ }^{2}$ See the following reports of the United Nations High Commissioner for Human Rights: A/HRC/15/33 (2010), A/HRC/12/19 (2009), A/HRC/5/7 (2007)
} 
identity can be masked by other identities resulting in systemic social inequality. This recognition of complex experiences offers a more comprehensive approach to research in order to "reveal the truth of history and thereby bring a more democratic truth to the forefront" (Fobear, 2014, p. 53).

\section{Power \& ideology limit access}

Access to resources and inclusion in official narratives is strongly dictated by power. Srilatha Batliwala proposes that power is "defined as the degree of control over material, human, intellectual and financial resources exercised by different sections of society" (as cited in VeneKlasen \& Miller, 2007, p. 41). Repressive regimes exert their power and control by deliberately rewriting history to deny atrocities in order to legitimize themselves and maintain their power and control (ICTJ, n.d.-a). Batliwala adds that a complete understanding of power must include recognition of its partner, ideology. Batliwala argues that societal institutions and structure are set up to reinforce the dominant ideology and the power of the dominant groups within that ideology (as cited in VeneKlasen \& Miller, 2007). When peacebuilding processes, particularly truthseeking initiatives, are created to serve a dominant ideology those who do not conform to that ideology will certainly be excluded. This exclusion may be passive due to the ignorance of the dominant ideology or active based on an alleged threat to those in power. This understanding of ideology's ability to dictate power validates Fobear's (2014) assertion that underlying nationalistic, patriarchal, and heteronormative messages have influenced the design of truth-seeking initiatives and limited the access of sexual and gender minorities to participate in them. Batliwala recommends that those with less power challenge societal institutions and structure until the challenges become strong enough to cause a complete transformation of a power structure (as cited in 
VeneKlasen \& Miller, 2007). This theory of change is echoed in the conversation between Lederach, Frieze, and Wheatley below.

\section{Societal change depends on networks}

When identifying the ability of leaders to create a tipping point for societal change, the literature revealed a theme of fostering critical connections or networks. Lederach (1997) identifies three types of leaders within the peacebuilding process: toplevel, middle-range, and grassroots leadership. Lederach offers an approach to identifying middle-range leadership that includes "consider[ing] the primary networks of groups and institutions that may exist within a setting” (1997, p. 41). Within this discussion of networks, Lederach focuses primarily on the key actors within them. He notes that middle-level leaders are uniquely characterized by their ability to be recognized by top-level leadership while simultaneously staying connected to their constituents. Lederach's middle-range leaders approach peacebuilding within the context of networking by focusing on the individual. These approaches include problemsolving workshops, training in conflict resolution, and peace commissions, among others. While Lederach highlights the significant role middle-level leaders play by building relationships with influential people through networks, Deborah Frieze and Margaret Wheatley (2006) of The Berkana Institute take the networking model further and argue that it is the first step in a process they call "emergence," in which life changes. They contend that making these critical connections with "kindred spirits" results in a process of scaling up efforts, the creation of a system much more powerful than the sum of its parts. Frieze and Wheately introduce the concept that these emerging systems in fact have greater capabilities, stronger qualities, and more intelligence than what exists within each individual. They advocate for better 
connections to like-minded people rather than better training programs for individuals. Frieze and Wheately recognize that emergence only happens through connections and have outlined this process as flowing from networks, to communities of practice, and finally to systems of influence. Lederach and Frieze and Wheately are presenting two aspects of the same conversation. Their combined contribution to the literature on leadership in social change provides us with a model for analyzing the roles of actors needed to facilitate networks and then predict the potential power of those networks to evolve and radically change society.

\section{Conceptual framework}

My conceptual framework is based on the analytical perspective provided by Lederach as described in the previous section. I particularly focus on middle-level leadership, commonly referred to in Colombia as civil society, primarily due to my limited access to leaders that fall in Lederach's three levels. See Figure 2 below for a complete description of Lederach's actors and approaches to peacebuilding. Lederach explains that a middle-out approach is conducted by a set of leaders situated in a particular location in the conflict and might be the critical component to create an infrastructure for peace. This infrastructure, Lederach explains, can be identified by three categories that make up middle-range approaches to peace: "problem-solving workshops, conflict resolution training, and the development of peace commissions" ( $\mathrm{p}$. 46). Lederach defines persons in the middle range as individuals who function in leadership positions within the conflict setting but who are not connected to or controlled by the authority of the formal government or major opposition movements 


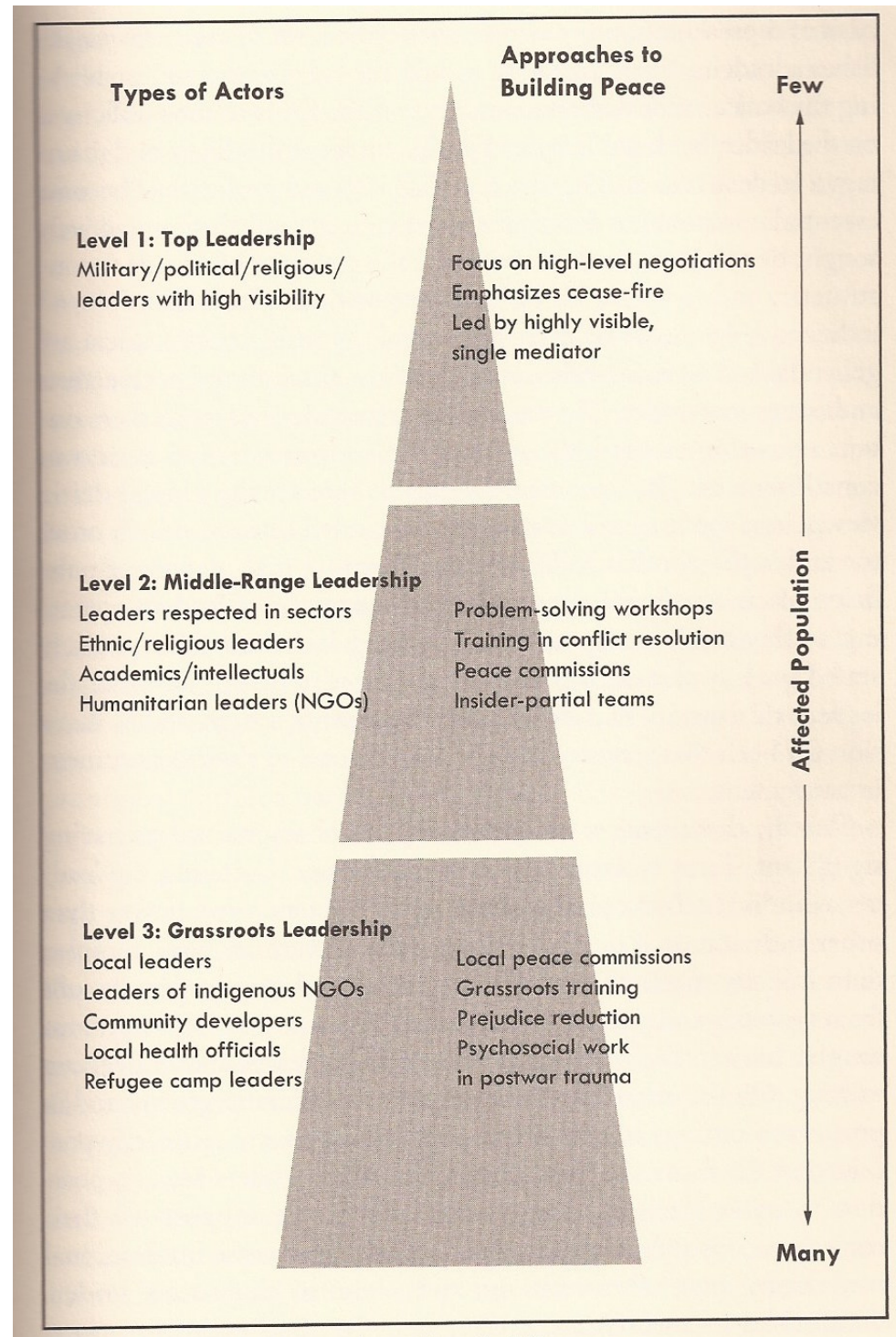

Figure 2. Actors and Approaches to Peacebuilding (Lederach, 1997)

\section{Practitioner Inquiry Design}

From a review of the literature, I have identified the following themes: First of all, inclusive truth-seeking initiatives are essential in peacebuilding; Secondly, power and dominant ideologies limit access of LGBTI people to peacebuilding processes; and thirdly, societal change depends upon networks built by individual leaders and 
organizations. These insights shed light upon the central question here, which is to what extent are civil society leaders in Colombia creating a peace process that is inclusive of LGBTI victims of the armed conflict? Particularly helpful is Lederach’s (1997) “middleout approach" to building peace which emphasizes the potential for middle-level leadership, or civil society, to utilize its positioning to create sustainable reconciliation through an infrastructure for peace. I was drawn to this perspective because of Colombia's vibrant civil society and the fact that the interests of the Colombian LGBTI population are advocated primarily by leaders and organizations within the middle range. Lederach discusses the dichotomous view of approaches to peacebuilding as either top-down or bottom-up and argues that his analytical perspective presents another option of being integrated and related. Therefore, it is not either or but both and.

Once I established my question, I began to seek answers while being guided by my conceptual framework anchored in Lederach. In order to find answers I conducted interviews, analyzed documents, and engaged in participatory observations.

Of the three prominent LGBTI organizations in Colombia - Caribe Afirmativo, Santamaría Fundación, and Colombia Diversa - only one of which is located in Bogotá. For interviews, I was able to secure a meeting with two employees from Colombia Diversa, based in Bogotá, after meeting their director at the transitional justice and LGBTI conference I attended. Attempts to secure interviews with other organizations were unsuccessful. For document analysis, I analyzed the recommendations made by two national LGBTI organizations to the Gender Subcommittee of the negotiation table. As a reflective practitioner, I also relied on my observations to support my research. My participatory observations were derived from my experience during my internship, 
attending the conference on transitional justice and the LGBTI population, and observations of other activities conducted my civil society organizations.

The limitations of this research design included the sample selection for interviews, where I was limited to representatives from organizations, as opposed to speaking directly with victims, and further limited by only gaining access to two employees from one organization. My research design was also limited by its focus on the middle range of society. This means that top-level programs by the government and grassroots efforts were not directly investigated. There is also a limitation to my understanding of the true causes of activities. I observed events and reviewed documents as an outsider and I was not privy to the behind-the-scenes efforts that actually influenced the decisions and activities that resulted in LGBTI inclusion or

exclusion. While I am fluent in Spanish, my native tongue is English; therefore, I may have missed certain underlying meanings or lacked a deeper understanding of certain documents that I reviewed in Spanish or even the exchanges during my interview.

\section{Presentation and analysis of data}

\section{Interview}

I conducted an interview with two employees of a prominent Colombian civil society organization for LGBTI people, Colombia Diversa. The two interviewees were both lawyer advocates for the organization. The interview focused on the role of Colombia Diversa in advocating on behalf of LGBTI people within the context of the armed conflict and the associated successes and challenges. Three main themes emerged from this discussion - a lack of information, societal prejudice and progress, and appropriate representation. 
Lack of information

Throughout the interview the reality of insufficient information was mentioned repeatedly and many times overlapped with the theme of social progress. One interviewee shared with me a report created by Colombia Diversa in 2006. This report outlined the status of human rights experienced by the LGBTI community. She explained that this report was the first of its kind in Colombia and one of the first in all of Latin America. The fact that this historic report was published only 10 years ago is an indication of the rate of social progression that impacts the inclusion of LGBTI interests and issues. She noted that the report does not include a focus on the armed conflict because there was simply not enough information. Therefore, any formal knowledge of the experience of LGBTI individuals within the context of the Colombian armed conflict is still in its youth. Both interviewees noted that even today, advocates like them don't fully understand how LGBTI people are treated in each community around the country, particularly in rural communities. The majority of the violence from the armed conflict has taken place in rural Colombia. These two realities paint a picture of an iceberg, where the information we have with regard to the LGBTI experience within the armed conflict is only the tip. One interviewee repeatedly referred to Colombia Diversa's role as documenting and shedding light on the LGBTI experience and I believe this is in direct response to the chasm of missing information.

One of the challenges identified to revealing more of the iceberg was insufficient funds. This limitation of resources confines Colombia Diversa's staff primarily to their office in Bogotá, keeping them disconnected from those living in smaller towns and rural villages. The information they receive is limited to the testimonies of those who are 
able to access them, such as their own friends, those living in the city, and even their staff (two members of Colombia Diversa's team have been murdered).

\section{Societal prejudice and progress}

Many of the other factors they identified as contributing to the lack of information were related to social progress. For example, one interviewee noted the milestone of decriminalizing homosexuality in 1981 as allowing them to finally join the discussion of victimization. She clarified that while being gay was no longer a crime, they did not enjoy any civil rights until 1991. Not only were LGBTI persons facing the difficulties of limited civil freedoms, but they were also challenging the notion of historically not being considered victims of the armed conflict like women, AfroColombians, and indigenous peoples have been. Societal prejudice has contributed to the lack of information through the inability to maintain accurate statistics. Another interviewee noted that there are still a handful of departments (states) that do not report the murder of gay people. Even when these murders are reported in other departments, if the individual is not living openly, then it is very difficult to accurately include their information. Many times the handling of a case like this is influenced by the wishes of the family who is not accepting of the individual's identity. One interviewee praised a particular prosecutor for deciding that if the individual's sexual or gender identity is related to the crime, then it cannot be kept secret. If more prosecutors took this stance, then the accuracy of information could improve. Unfortunately, many of these judicial proceedings are still the product of social taboos and discrimination.

Social progress has also impacted the ability to discuss LGBTI experiences. One interviewee pointed out that the terms commonly used today to identify LGBTI 
individuals did not exist prior to the year 2000. She described many communities as having their own slang for a general derogatory term but society lacked respectful terminology to promote discussion. According to her, an organization that was formally established in 2003 but began its initial work in 2000 named Planeta Paz was the first to begin to talk about peace and the LGBTI perspective. In 2011, as part of the Victims and Land Restitution Law 1448, LGBTI persons were able to register with the government as victims of the armed conflict along with other groups such as women and indigenous peoples. She was critical of this progress comparing the LGBTI journey to that of women's movements. She noted that while women victims of the conflict have made many strides in transitional justice measures, LGBTI victims still do not have any demonstration of historic memory such as a physical memorial, nor have they received any collective or individual reparations.

Societal prejudice has maintained the perception of LGBTI people as immoral, prostitutes, and drug addicts. This perception has been perpetuated by armed groups in rural communities who would make threats and distribute pamphlets announcing the cleansing of a community through the removal of LGBTI persons, either by murder or the individual's flight. These threats and pamphlets are directly related to the armed conflict they were often used as control tactics by guerrilla and paramilitary groups. Many times these pamphlets are posted prominently in communities and the threats are carried out publicly. An interesting question for consideration was raised in the interview about the role of the community in protecting these crimes and maintaining silence around them, in addition to the role of the perpetrators. Much of these extreme manifestations of societal prejudice take place in the rural sections of Colombia creating a disparity between the LGBTI experience in urban and rural areas. If much of the 
extreme violence against the LGBTI population occurs in the rural context, but the majority of the information gathered about the LGBTI experience comes from those living in urban areas, then how much progress is truly being made towards revealing the largest portion of the iceberg?

\section{Appropriate representation}

Finally, this interview highlighted the issue of appropriate representation both specifically within the LGBTI community as well as generally among victims groups. Both interviewees acknowledged that the compounding factor of multiple identities increased the risk of violence for an individual. For example, an Afro trans woman is much more likely to experience violence than a white gay man. This complexity of identities creates a challenge in representation - which identity receives priority? When asked how their organization would make this distinction when analyzing cases, neither interviewee could provide a coherent response. One discussed the challenge of representation among victims groups and expressed her feelings that women receive first priority. She summarized her experiences at conferences, forums, and other gatherings where the voices of women advocates always spoke first and loudest. She hinted at an air of competition among the groups and stated the LGBTI issues are last.

With regard to appropriate representation specifically within the LGBTI community, an interviewee commented that it's important to be critical of who the speakers are on behalf of the community. She noted that they have primarily been gay men, adding that only one woman was represented in Havana, Cuba at the negotiation table as a representative of LGBTI interests. It's also common, she said, for trans women to be speakers for the community but very rarely do you see lesbians and trans men in 
the spotlight. This might be related to the pervasiveness of patriarchy that cannot be escaped even within the queer community. Therefore, the voices of a very diverse group become extremely limited.

Finally, an interviewee outlined the error made in appropriate representation when it was dictated by legislation. She explained that according to the Law 1448, local "tables" of representation were created for LGBTI people in different communities across the country. The individuals appointed to these "tables" were tasked with representing LGBTI interests in Havana. However, these positions were staffed by outsiders with no connection to the community resulting in the failure of the proposed direct involvement by the LGBTI community in the peace negotiations. According to her, the government recognized this failure in appropriate representation and in response invited leaders of established LGBTI organizations, who had connections to the people, and allowed them to address the negotiators in Havana advocating on behalf of LGBTI interests.

In summary, the interviewees highlighted the multi-faceted challenge of an overarching lack of information and documentation, progress and setback with regard to societal prejudice, and a need to overcome an oppressive hierarchy in order to achieve appropriate representation. When reflecting critically on the interview and the perspectives provided, a few questions came to mind. How does the privileged position of Colombia Diversa impact its analysis? The office is located in the capital city of Bogotá and is staffed by many white, well-educated individuals. How would the perspective of another organization like Caribe Afirmativo, which is located in Barranquilla and staffed by more black and brown individuals, differ? Would an organization located outside of Bogotá have more connection to the rural experience? 
The two individuals I interviewed were lawyers, how did that impact their analysis of the situation? These are just a few of the limitations inherent in this interview.

All in all, this interview contributed to answering my research question by revealing that these civil society leaders are engaging in the work of documenting the conflict-related violence committed against the LGBTI population in order to create a more inclusive peace process. They are also challenging traditional stereotypes and prejudices that keep the LGBTI population on the periphery of the peace process by advocating for non-discriminatory practices and policies.

\section{Presentations to the negotiation table by LGBTI organizations}

On February 11 and March 6, 2015, the members of the negotiation table invited two prominent LGBTI civil society organizations to address a gender subcommittee of the table during their exploration of point six in the agenda, victims of the armed conflict. An invitation of this type had never been extended in any previous peace talks

worldwide. The opportunity to present the perspective of such a marginalized group was truly historic. The two organizations were Corporación Caribe Afirmativo and Colombia Diversa, represented at the subcommittee by their respective Executive Directors, Wilson Castañeda Castro and Mauricio Albarracín. Below is my analysis of their speeches to the subcommittee.

Castañeda gave his address first on February 11, 2015 and structured his speech around the LGBTI experience with violence in the armed conflict and the lack of truth surrounding that violence. Albarracín complemented Castañeda's speech by including many specific recommendations for adjustments to the negotiators' agreements, making references to particular evidence and legal documents and policies. Both organizations 
emphasized the importance of discovering the full truth with regard to the violence experienced by the LGBTI population during the armed conflict and once that truth is revealed, acknowledgement of wrongdoing and a plea for forgiveness are required.

The comments made to the gender subcommittee highlight a distinction as well as a complimentary relationship between societal and institutional structures that have played a role in perpetuating and hiding the violence against LGBTI individuals. They identified this violence as taking the form of homicides, forced displacements, threatening pamphlets, and physical assaults.

\section{Societal structures}

Caribe Afirmativo and Colombia Diversa painted a picture of LGBTI people living as second-class citizens, describing a country of exclusion, discrimination, and sheer denial of diverse gender identities, sexes, and sexual orientations. Caribe Afirmativo also noted the important role language plays in promoting traditional logic of patriarchy and exclusion creating an intolerant society increasing LGBTI vulnerability.

Colombia Diversa pointed out that the LGBTI movement has engaged in its fight during the same period that the armed conflict has occurred, noting the indiscriminant way in which the violence has destroyed every day life. This reality of time periods confounds the social structures that present challenges for the LGBTI movement with the social reactions to violence that may otherwise not be present. This blurring of social structures can be highlighted in the unique rural experience of LGBTI persons and the armed conflict. Colombia Diversa argued that prejudices against LGBTI people have been strengthened in rural areas through the use of violence. This creates a challenge for the LGBTI movement where it not only has to overcome traditional values that are 
unaccepting of them, but they also need to overcome traditional values that are more deeply held as a survival response. How can the LGBTI movement build allies when any behavior that is seemingly sympathetic to LGBTI persons could directly threaten an ally's life? LGBTI persons are forced to flee rural areas in search of big cities where they might find some respite from discrimination and threats to their being, creating another layer of displacement outside of the direct orders to leave a community. Why are cities able to offer an experience different from rural communities?

The complexity of the rural experience will not be sufficiently explored within the confines of this paper; however, my studies have revealed some insight. The violence is stronger in rural areas of Colombia partially because that is historically where the government has had minimal presence, resulting in the unmet needs of farmers fueling their rebellion, which was then able to maintain itself because of the lack of government presence. Therefore, violent behaviors of any kind were more prevalent in rural areas. A lack of government presence also meant the creation of social norms outside of legal guidelines; therefore, as LGBTI people may have gained certain legal protections over the years, these were not implemented in rural communities. Like Colombia Diversa noted, prejudices against LGBTI people have been maintained and deepened in rural areas. We know that traditional views tend to sustain themselves in rural communities longer than in urban communities where there is a clash of multiple worldviews. Colombia Diversa adds that these prejudicial viewpoints weren't just sustained but intensified through the use of violence, which creates a more vulnerable and dangerous environment for those who do not conform to the traditionally held concepts. Caribe Afirmativo echoes this perspective in its warning against the tendency to strengthen attitudes of nationalism when reconstructing a nation. Caribe Afirmativo argues that 
this national identity can reinforce traditional gender roles and notions of honor that marginalize and even erase differences that threaten minority groups like LGBTI people.

\section{Institutional structures}

One of the biggest challenges both Caribe Afirmativo and Colombia Diversa mentioned in their speeches was uncovering the truth. So it comes as no surprise that when a case is finally brought before the justice system, that the high rates of impunity are nothing less than demoralizing. Colombia Diversa described their efforts in documenting and pursuing cases of crimes committed against LGBTI persons noting a distinction between perpetrators within paramilitary groups, the State, and guerrilla groups. As of this speech, Colombia Diversa had successfully prosecuted only one case within the paramilitary ranks and was tracking 45 others with less success.

Impunity may partially be the result of another area of insufficiency within institutional structures: inadequate or nonexistent legal protections. Caribe Afirmativo identified that public policy does not explicitly prohibit discrimination on the basis of sexual orientation, gender identity, and gender expression. If these behaviors are not disallowed, then the courts certainly cannot be expected to punish perpetrators who target LGBTI people neither within the context of civilian life nor that of the armed conflict. In order for LGBTI victims of the armed conflict to be fully included in its peace process, they must also be fully included in the legal structures that rule over peacetime. According to Colombia Diversa, legal protection begins with public declarations by both the Colombian government and the FARC denouncing discrimination towards the LGBTI population, much like they did for women. Statements are not enough and 
must be followed my concrete legal protections where LGBTI people are the subject of that protection.

Many of the issues presented by the two organizations are interrelated. The conversation of impunity led into the discussion of inadequate legal protections, which brings us to the general security and safety of LGBTI people. Of particular concern for both organizations was the safety of LGBTI persons in the post conflict setting. Therefore, denouncing LGBTI discrimination and the creation of proper legal protections is significant not only in identifying and prosecuting past crimes, but also in preventing future ones as the country grapples with its transition from war to peace.

Legal protections will only be effective if crimes are identified and their perpetrators are held accountable. This requires the documentation of crimes, which both Caribe Afirmativo and Colombia Diversa shared were woefully under reported. One aspect contributing to the inadequate record of crimes committed against LGBTI persons may be rigid definitions of gender and sexuality, which limit the full acknowledgment of violence. In order to address this in the post-conflict era, Caribe Afirmativo reinforces the need to implement a gender lens for all agreements drafted between the negotiating parties.

Colombia Diversa points out an unprecedented exclusion of the LGBTI population in political participation. Colombia Diversa makes reference to specific agreements coming from the negotiators and urges them to explicitly include the rights of LGBTI individuals and the LGBTI movement in each. For example, Colombia Diversa makes a recommendation with regard to the National Council on Reconciliation and Coexistence - an entity being proposed by the negotiators - to explicitly include the LGBTI population in its mandate like it has with other groups. Within this call for 
inclusion in an institutional structure, Colombia Diversa adds a suggestion to the function of the Council that is focused on the societal impact. They advocate that the Council promote actions to guarantee equality, the acknowledgment of others, and nondiscrimination, in order to change perspectives that sustain stereotypes and prejudices. Colombia Diversa's recommendations highlight the blurred lines between the institutional and the societal in the construction of a peaceful Colombia.

This overlap between institutional and social structures is also apparent in the non-peaceful era of Colombia. Caribe Afirmativo argued that armed actors operated under social ideas of "decency, morality, and normality" in order to control communities and the bodies of individuals within the context of the conflict. Caribe Afirmativo stated that legal and institutional reform is insufficient to change social and cultural practices but it is evident through their requests that both organizations are acknowledging the role the Colombian government and the FARC play in shaping societal behavior.

Finally, discovering the truth was the most prominent theme found in both addresses to the subcommittee. This process of revealing the truth of what has happened will require much of both the societal and institutional structures, much of which has been outlined above. Colombia Diversa compares the LGBTI movement's struggle for equality to the country's struggle for peace. They note that peace is diversity, it is the recognition of one another, and articulate that one's body is the first territory of peace.

In summary, the analysis of these recommendations made directly to the negotiation table further answered my research question by revealing that civil society leaders are creating an inclusive peace process for LGBTI victims by actually bringing 
their voices to the peace table. They were also demanding a right to truth for the LGBTI victims in the form of recognition and acknowledgment.

\section{Participatory Observations}

\section{Description of overall project}

The conference I have referenced throughout my paper thus far will now be described in full detail. My practicum site, International Center for Transitional Justice (ICTJ), conducted a project in collaboration with NGOs in the LGBTI movement and government institutions that were working in the area of LGBTI rights. This project included two regional workshops and one national forum. The national conference was the component of this project that I have previously described. This project was titled "Assessing and promoting access by LGBTI victims of the armed conflict to transitional justice mechanisms." The two regional workshops were held in the cities of Cali and Maicao, while the national forum was held in the capital city of Bogotá. The two-day national conference served as the closing event for this project and included two panel discussions on the first day of national and international experts on transitional justice, and truth and memory initiatives. Day one also included a workshop that explored the harm suffered by the LGBTI population within the context of the armed conflict. Day two consisted of a working session that included a meeting with the Office of the High Commissioner for Peace. The working session explored topics such as the current state of the peace process, what are LGBTI organizations doing and how, who are the actors, key issue areas for the LGBTI population, and a discussion of what they have and what they want. The proposed outcome of these three events was the design of an advocacy plan to raise awareness of the violations committed by illegal armed groups against 
members of the LGBTI community, and improve their access to transitional justice mechanisms, particularly truth-seeking and memory initiatives. Unfortunately, this project was not completed during my internship time; therefore, I do not have information on whether the stated outcome was achieved.

\section{Description of my participation and observations}

After opening remarks and a panel discussion about the challenges of transitional justice and the peace process facing the LGBTI population, the conference room divided into six different groups. I stayed in my chair at the back of the room, feeling unsure of how to participate since I'm not a member of the LGBTI population and was no longer an intern for one of the organizing groups. While I sat back dealing with my discomfort, the groups began to share stories of people who were targeted for harassment, disappearance, and even murder because of their association with the LGBTI community. Each group then chose one story to explore in depth. The activity continued in a world café style, with one "host" from each group staying behind and sharing the chosen story with the new group. Each new discussion was prompted by a question examining themes like the victim's targeted identities or behaviors, the harm inflicted upon the individual and/or the community, and possible community responses that could have prevented the incident. I decided to join a group during the second round and listened to a story of a young woman. I briefly described this story in the introduction of this paper.

The discussion following the story circled around whether she was targeted for being a woman, being an advocate for women, or for being a lesbian. The interconnectedness of identities made this story even more complex and highlighted the 
multiple levels of vulnerabilities one can experience within the context of Colombia's armed conflict. The challenge the participants faced in explaining the motive for her target relates to the literature with regard to Fobear's (2014) contribution that the intersectionality of identities reveals how certain identities can be masked by others. The discussion surrounding this story also revealed the difficulties faced by lawyers to develop a clear and strong case on behalf of LGBTI victims; it revealed the mixed societal feelings on LGBTI people's behavior and who to blame for violent crimes against them; and it ultimately revealed the long road ahead legally, socially, and personally for Colombians in order to find reconciliation after a half-century long internal armed conflict.

In summary, my observations revealed some themes found in the literature actually playing out before me. The activities I observed being conducted by my organization as well as the others were never conducted solo. They were regularly partnering to conduct workshops, training, and conferences around the country in order to build that network that was discussed by Lederach and Frieze and Wheatley. Their activities addressed both strategies, the individual and the collective approaches to network building. Realizing the challenge of reaching the most affected areas for victims of the armed conflict, the rural areas, the network strategies employed will hopefully help overcome that challenge. My observations also revealed that the importance of truth seeking that was discussed in the literature was also apparent in practice. This was evidenced by day one of the conference being entirely dedicated to story telling and creating space for LGBTI victims to reveal the truth. My observations also revealed another connection to the literature by demonstrating middle level leadership activities as described by Lederach. The second day of the conference was dedicated to a working 
session with the Office of the High Commissioner for Peace. This provided the victim participants with an opportunity to submit proposals for a peace agenda that was coordinated by civil society actors.

\section{Observations of other civil society activities}

Other notable activities include Caribe Afirmativo's traveling forums and dialogues that took place in six Colombian cities: Cartagena, Florencia, Montería, Pasto (Nariño), Popayán, and Riohacha. These efforts are designed to train LGBTI leaders and social organizations in order to promote mobilization among the population around the postconflict and peace agendas, including the construction of memory (Caribe Afirmativo, 2016). On April 7 \& 8, 2016 Caribe Afirmativo in partnership with a German foundation held the first citizen forum in Colombia for historically discriminated groups and the peace process. This forum took place in Cartagena and Barranquilla with the intention of discovering how the armed conflict furthered their experience of exclusion and denial of rights (Caribe Afirmativo, 2016)

All of these forums, training, and conferences conducted by civil society organizations are examples of societal change through networks. Each activist or each organization cannot alone reach all of Colombian society; therefore they work together in joint forums spread throughout the country to connect with as many people as possible. This way they are better able to inform victims of their rights, train local leaders to continue the cause, include a variety of voices in a peace agenda, slowly reveal the truth, and ultimately create a peaceful Colombia where LGBTI individuals are wellinformed, active, and protected citizens. 
The National Center for Historical Memory (CNMH) launched its report on the experience of LGBTI persons within the context of the armed conflict title "Aniquilar la Diferencia” (Annihilate the Difference) on April 27, 2016. Colombia Diversa mentioned this project by the $\mathrm{CNMH}$ in its 2015 address to the negotiators when commenting on the truth deficit that exists with regard to violence against LGBTI persons within the armed conflict. They noted that the CNMH was in the preliminary and exploratory stages of a report on the topic. The report documents the stories of 63 victims from four departments (Colombian states) who participated in the study and registered more than 2,000 victimizing events. Now that the report has been released, Caribe Afirmativo reacted to it by highlighting three important components: it established a starting point for authorities to take action to protect LGBTI people in their departments; it is the first publication to document the violence committed against LGBTI people and the impact on their families, revealing the invisible nature of the violence; lastly, the launch of the report included three LGBTI victims, including a lesbian who shared being sexually assaulted by an illegal armed actor in order to convince her that she should love a man. "Annihilate the Difference" is an historic report because for the first time LGBTI people are officially recognized as having suffered from this violence within the armed conflict (Caribe Afirmativo, 2016). This report reinforces the focus on truth for the inclusion of LGBTI victims of the armed conflict.

\section{Discussion}

\section{Conclusions}

All in all, my research revealed a few answers to my research question: to what extent are civil society leaders in Colombia creating a peace process that is inclusive of 
LGBTI victims of the armed conflict? They are documenting the victimization of the LGBTI population as revealed in my interview with Colombia Diversa. They are bringing LGBTI voices to the peace table through directly addressing the Gender Subcommittee and making collective recommendations on behalf of an LGBTI peace agenda. They are demanding the right to truth through recognition and acknowledgment as demonstrated by my interviews with Colombia Diversa as well as the recommendations made to the Gender Subcommittee. Civil society organizations are building networks for social change by partnering with other organization to conduct capacity building activities in urban and rural settings and utilizing the different assets and connections of each organization to effectively reach a greater variety of LGBTI victims of the armed conflict. Finally, civil society leaders are impact the agreements developed by the negotiators. As indicated by Virginia Bouvier with the United Stated Institute for Peace, Colombia's draft agreements on victims are more inclusive of the victims than any other peace process has been. I was also able to read the draft agreement on victims and the majority of the themes of recommendations made by the LGBTI organizations to the Gender Subcommittee were included. This reveals the credibility given to these organizations by the negotiators as well as their willingness to make a real change and not just spout appealing rhetoric. Unfortunately, a final agreement has not been signed and the peace process is still underway. Therefore, we do not yet know the actual impact of these civil society leaders' efforts on the inclusion of LGBTI victims.

Another challenge that has yet to be resolved by the LGBTI movement is overcoming the societal dynamics. These social constructs that promoted LGBTI discrimination and ultimately violence, existed prior to the conflict and will undoubtedly persist after a peace agreement is signed. These constructs gave way for the patterns of 
violence committed against LGBTI persons within the armed conflict. Therefore, civil society leaders and the LGBTI movement must uncover the historical context and truth of the LGBTI experience in Colombia in order to full reveal the armed conflict experience, creating an enormous task. They are simultaneously fighting historic social prejudice and exclusion while fighting discrimination and invisibility within the armed conflict.

I'd like to offer a different perspective on the role of truth-seeking initiatives. While truth-seeking initiatives in transitional justice and truth commissions in peacebuilding efforts are typically implemented in "post-conflict" times, after a formal peace agreement has been signed, Colombia shows the influential role truth-seeking initiatives play early on and their potential impact on an entire peace process. The experience of LGBTI victims of the armed conflict has revealed that the truth of their victimization must be revealed and acknowledged if they are even to be considered as having a place in the peace process. If their truth-seeking efforts only occur post-peace agreement, then they will not have been included in policies for reparations or justice. My research has led me to the conclusion that truth is an essential component from beginning to end.

There is another unresolved challenge facing the LGBTI population in Colombia with regard to acknowledging the violence they've experienced within the context of the armed conflict. I was unable to find a clear process by which instances of LGBTI violence were clearly differentiated between the armed conflict violence and the structural violence LGBTI individuals experience in the broader society. During the national conference in Bogotá, ICTJ's Gender Justice Program Director, Kelli Muddell (2015) highlighted two major perspective dilemmas: (1) violence against LGBTI 
individuals is normal; and (2) violence during conflict times is random and falls outside the scope of the conflict. This first perspective dilemma adds to the difficulty of differentiating conflict and structural violence. This seems to be challenging even for LGBTI individuals who have suffered for generations and have come to know life in society as a sexual minority is met with violence. A common theme throughout the conference was the support for an investigation into the cultural roots of the armed conflict and an historical reparations process for the LGBTI population. I believe this speaks to the desire to know the truth of the present while recognizing the pain of the past and acknowledging that this experience of violence may be different because of the armed conflict but is one part of a violent history for the Colombian LGBTI population.

Another reason for the difficulty in differentiating the violence is that their justifications are very similar. Muddell (2015) commented on the fact that Colombian paramilitaries and guerrillas justified their cleansing efforts by stating that LGBTI people don't conform to the Colombian standard. This rationale may be very similar to that which is used to promote structural violence, the difference, however, is in the underlying motive. The violence committed during the armed conflict is motivated by the need of those in power or seeking power to find the marginalized groups to consolidate their power. While the motive within structural violence may also be rooted in power, it likely has other social and religious discriminatory roots.

\section{Practical Applicability}

"To be at all germane to contemporary conflict, peacebuilding must be rooted in and responsive to the experiential and subjective realities shaping people's perspectives and needs...conceptual paradigm and praxis of peacebuilding must shift significantly 
away from the traditional framework and activities that make up statist diplomacy" (Lederach, 1997, p. 24). This provides insight into why Colombia was referred to as a world model by USIP, Colombia truly is responding to the realities of the victims and taking measures to ensure their negotiations are rooted in those experiences. Other societies in transition may benefit from understanding and adapting the Colombian model in order to create a new framework for peacebuilding that is in line with Lederach's recommendations.

\section{Recommendations for Further Research}

Kelli Muddell warned against the majority identity within the LGBTI population overshadowing and claiming to represent the experiences of minority LGBTI identities. This was also revealed in my interview with Colombia Diversa and their struggle with appropriate representation. Practitioners could benefit from understanding how to gain insight into and combat oppressive hierarchies that exist even within historically marginalized groups. This would ensure more effective efforts by civil society leaders in creating a non-oppressive and comprehensively inclusive process.

Human "relationship is the basis of both the conflict and its long-term solution" (Lederach, 1997, p. 26). Successful peacebuilding paradigms for today's conflicts must move "away from a concern with the resolution of issues and toward a frame of reference that focuses on the restoration and rebuilding of relationships" (Lederach, 1997, p. 24). Colombia has been extremely focused on the resolution of issues. Its negotiators at the peace table identified a six-point agenda for the negotiation and have been working methodically to create agreements from both sides on each issue area. The six points include: rural reform, political participation, illicit drugs, victims, end of 
conflict, and implementation. I believe this focus on relationships has been lacking in Colombia's peace process and will come to the forefront once a final peace agreement is reached and the guerrillas must reintegrate into society. Reintegration has already occurred in small ways as fighters abandon the ranks or as smaller guerrilla groups disband. The negotiators are aware of the importance of reintegration because the topic is part of two issue areas - end of conflict and implementation. However, relational reconciliation will not occur because some law has outlined that it will. Further research should be done exploring the reintegration process and relational healing that has already occurred with former guerrilla fighters. Further research should be conducted to document what efforts, if any, are being done to promote relational reconciliation within Colombian communities before and after agreements on reintegration are made at the peace table. This research is crucial as much of the war took place in rural areas and the FARC recruited rural fighters who will be returning to the very communities they terrorized.

Finally, research should be conducted on the perception of inclusion by individual LGBTI victims of the armed conflict. This paper focused on middle level society and the more collective efforts of leadership. While my research may have revealed some inclusive activities, it did not shed light on whether this has impacted the daily lived experience of LGBTI victims. A better understanding of the sense of empowerment among LGBTI victims in the peace process is necessary. 


\section{BIBLIOGRAPHY}

Alsema, A. (2012, August 28). History of peace talks in Colombia. Retrieved November 21, 2015, from Colombia Reports: http://colombiareports.com/peace-talks-colombiafarc-eln/

BBC. (2013, August 29). Profiles: Colombia's armed groups. Retrieved November 21, 2015, from BBC News: http://www.bbc.com/news/world-latin-america-11400950

Caribe Afirmativo. (2016, March 15). Caribe Afirmativo trains LGBTI victims of the armed conflict. Retrieved May 16, 2016, from Caribe Afirmativo:

http://caribeafirmativo.lgbt/2016/03/15/caribe-afirmativo-capacita-a-personaslgbti-victimas-del-conflicto/

Caribe Afirmativo. (2016, April 14). First event of historically discriminated groups on the peace process. Retrieved May 16, 2016, from Caribe Afirmativo:

http://caribeafirmativo.lgbt/2016/04/14/primer-evento-grupos-historicamentediscriminados-proceso-paz/

Caribe Afirmativo. (2016, April 29). Three key moments in the launch of the report on LGBTI victims in the armed conflict. Retrieved May 16, 2016, from Caribe Afirmativo: http://caribeafirmativo.lgbt/2016/04/29/tres-momentos-clave-lanzamientoinforme-victimas-lgbt-del-conflicto/

Fischer, M. (2011). Civil society in conflict transformation: strengths and limitations. In M. F. B. Austin, Advancing Conflict Transformation: The Berghof Handbook II (pp. 287313). Opladen/Framington Hills: Barbara Budrich Publishers.

Fobear, K. (2014). Queering Truth Commissions. Journal of Human Rights Practice, 6 (1), 51-68. 
ICTJ. (n.d.-a). Truth and memory. Retrieved November 21, 2015, from International Center for Transitional Justice: https://www.ictj.org/our-work/transitional-justiceissues/truth-and-memory

ICTJ. (n.d.-b). What is transitional justice? Retrieved November 21, 2015, from International Center for Transitional Justice: https://www.ictj.org/about/transitional-justice Lederach, J. P. (1997). Building peace: sustainable reconciliation in divided societies. Washington, D.C.: United States Institute of Peace Press.

Muddell, K. (2015, March). International perspective on the challenges of transitional justice for the LGBTI population. Challenges of transitional justice and the peace process facing the LGBTI population. Bogota, Colombia.

Red Nacional de Informacion. (2016, May 1). Registro unico de victimas. Retrieved May 18, 2016, from Unidad para la atencion y reparacion integral de las victimas: http://rni.unidadvictimas.gov.co/?q=node/107

Renwick, D., \& Hanson, S. (2014, December 1). FARC, ELN: Colombia's left-wing guerrillas. Retrieved November 21, 2015, from Council on foreign relations: http://www.cfr.org/colombia/farc-eln-colombias-left-wing-guerrillas/p9272

Strasser, F. (2015, September 24). Q\&A: Colombia breakthrough a world model for peace talks. Retrieved November 21, 2015, from United State Institute of Peace: http://www.usip.org/publications/2015/09/24/qa-colombia-breakthrough-worldmodel-peace-talks

United Nations. (2010). Guidance Note of the Secretary-General: United Nations Approach to Transitional Justice. United Nations. 
VeneKlasen, L., \& Miller, V. (2007). A New Weave of Power, People \& Politics: The Action Guide for Advocacy and Citizen Participation. Rugby, United Kingdom: Practical Action Publishing. 


\section{APPENDICES}

Appendix A: Interview questions for advocates from Colombia Diversa in English and Spanish

1) Can you please share with me what is your title and role here at Colombia Diversa? ¿Puede por favor compartir conmigo cual es su título y su papel aquí en Colombia Diversa?

2) Tell me about Colombia Diversa. What function does the organization play within the context of Colombian civil society peacebuilding efforts? Cuénteme sobre Colombia Diversa. ¿Cuál es su función dentro del contexto de los esfuerzos de la sociedad civil Colombiana para la construcción de paz?

3) How does Colombia Diversa construct identities for the collective representation? ¿Cómo construye Colombia Diversa las identidades para la representación colectiva?

a. How do members of the LGBTI population access your services? Do you represent individual interests or use individual information to inform collective representation? ¿Cómo los miembros de la población LGBTI pueden acceder a sus servicios? ¿Representan los intereses individuales o utilizan la información individual para informar a la representación colectiva?

4) Acknowledging the complex intersectionality of identities, how does your organization identify a victim of the armed conflict as being targeted for their sexual orientation or gender construction or identity? Reconociendo la compleja interseccionalidad de las identidades, ¿Cómo identificar a una víctima del conflicto armado que fue atacada por su orientación sexual, construcción de genero o identidad?

5) How are peacebuilding efforts by the LGBTI population different from other victim groups? ¿Cómo son los esfuerzos de la construcción de paz por parte de la población LGBTI distintos a otros grupos de víctimas?

6) What are critical factors for your effectiveness? ¿Cuáles son los factores críticos para su efectividad?

7) What insights can we learn about the transitional justice process based on your advocacy for the LGBTI population? ¿Qué ideas podemos aprender sobre el proceso de la justicia transicional con base a su defensa de la población LGBTI?

8) Any other reflections? ¿Qué otras contribuciones le gustaría añadir? 